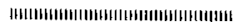

技術資料

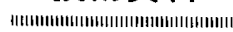

\title{
製鋼用アーク炉の電磁障害と対策
}

和泉喜久磨*

\section{EMI and Countermeasure for Electric Arc Furnace in Steelmaking}

\section{Kikuma Izumi}

\section{Synopsis}

An electric arc furnace in steelmaking which melts scraps by arc heating, is one of the most important equipments in recycle system for iron and steel.

At present the product of electric steelmaking is about $30 \%$ of the crude steel.

Toward the 21st century, the neccesity of electric arc furnace becomes large in order to recycle scraps in clean environment.

In this paper the problem about Electro-Magnetic Interference of electric arc furnace in steelmaking, and countermeasure for these problems are described, such as flicker, harmonic waves and magnetic effect.

\section{1.はじめに}

21世紀に向かって「廃棄物」を「クリーン」に 「リサイクル」することが大きなテーマとして注 目をあびて扣り，それに伴い電磁気障害（EMI） に対しても，近年関心が高まってきた。

製鋼用フーク怇は，産業廃棄物であるスクラッ ブを, アーク加熱により溶解し，成分を調整する ことにより新しい鋼とする鉄りサイクルの主要設 備の 1 つである。

また，1990年の製鋼用フーク炉にお゙ける生産量 は，約3 500万トンに達した。これは前年比 $5 \%$ のの 増加で，全粗鋼生産量の約 $32 \%$ に当り，1980年以 後は、スクラッブ蓄積量の増大などもあり漸增傾 向は依然として続いている。

本稿では，製鋼用アーク炬の電磁障害とその対

1991年 4 月 22 日受付

*大同特殊鋼蛛機械事業部
策について, 従来からの交流アーク炉 (AC炉) 飞 最近注目を集めている直流アーク炉 (DC炉)を比 較して整理した。

2. 交流アーク炉と直流アーク炉

製鋼用フーク炉は，大別して，装入原料溶解の 容器としての炬体とフーク熱供給源の電気設備で 構成され，供給電源の区別により $\mathrm{AC}$ 炬と DC 炬 に区分される。

$\mathrm{AC}$ 炬は三相交流を 3 本の上部黒鉛電極に印加 乙，炉内に装入された被溶解物(スクラップなど） を中性点として被溶解物として上部電極との間に アークを発生させ，その熱によってスクラップを 溶解させる。

一方，DC 炉は，三相交流をサイリスタ整流装置 により直流に变換し，上部黒鉛電極之炉体底部に 設置した炉底電極との間にその直流電圧を印加 し，被加熱物を介してアークを発生させスクラッ ブを溶解する。 
製鋼用アーク炬は，現在大半が AC 炬である。 $\mathrm{DC}$ 炬は，開発段階にあり，国内では1991年 4 月現 在 6 基稼動して扣り,最大のものは溶鋼重量 130 卜 ン, 师かく内径 $7.0 \mathrm{~m}$, 变圧器容量100MVA の炉が 実用化されている。AC炬に比べて，DC 炉の利点 が多いことが注目を集めており，計画中のアーク 炬のほとんどが DC 炉であることから，2－3 年 内には15基を超えると予想される。

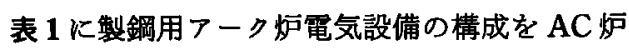
と DC 师を比較して示す。

\section{3. アーク炉の電磁障害とその対策}

製鋼用アーク炉は，産業廃棄物をリサイクルす る素晴しい機能を発揮し社会に貢献している。し
かし，同時に電磁障害す発生するため，その対策 の設備に, アーク炉設備之同程度の設備費用が費 やされる。

表 2 にフーク炉の発生する電磁障害とその対策 のための設備を整理した。

\section{1 伝播性電磁障害}

アーク炉の負荷変動は，電力系統に各種の影響 を与えるスクラッブを加熱するためのアークの発 生が，電極とスクラップの距離やそれからの状態 が変化すると不連続となり，そのため電流および 電压の波形が不規則になったり，電力が急激に変 化したりして，電力系統に悪影響を与える にフーク炬の電王, 電流, 電力の測定例を示す2)。 上記に述べたアーク炉の問題点を整理すると以

表 $1 \mathrm{DC}$ 戸 $/ \mathrm{AC}$ 炉電気設備構成

\begin{tabular}{|c|c|c|c|}
\hline 項 & 目 & DC炉 & AC炉 \\
\hline 特 高 & 機 器 & $\begin{array}{l}\text { 炉用VCB } \\
\text { 避雷器/サージ吸収器 }\end{array}$ & $\begin{array}{l}\text { 炉用VCB } \\
\text { 避雷器／サージ吸収器 }\end{array}$ \\
\hline 電 & 源 & $\begin{array}{l}\text { 整流器用変圧器 } \\
\text { サイリスタ整流器 } \\
\text { 直流リアクトル }\end{array}$ & 炉用変圧器 \\
\hline タップ女 & 刀換装置 & $\begin{array}{l}\text { 無電圧タップ切換装置 } \\
\text { または } \\
\text { 負荷時タップ切換装䈯 } \\
\text { ( } 5 \text {-10点) }\end{array}$ & $\begin{array}{l}\text { 負荷時タップ切換装置 } \\
(5 \sim 10 \text { 点 })\end{array}$ \\
\hline 二 次 & 導 体 & $\begin{array}{l}\text { 大電流母線 } \\
\text { (直流用陽極側, 陰極側) }\end{array}$ & $\begin{array}{l}\text { 大電流母線 } \\
\text { (AC三相分) }\end{array}$ \\
\hline \multirow[b]{2}{*}{ 電極 } & 上 部 & 黒鉛電極 $\quad 1$ 本 & 黒鉛電極 3 本 \\
\hline & 炉 底 & 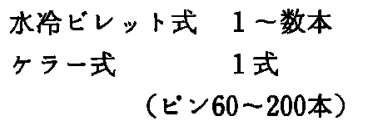 & なし \\
\hline \multicolumn{2}{|c|}{ 電極昇降䍗 } & $\begin{array}{l}\text { 電動機式 } \\
\text { 液 圧 式 }\end{array}$ & $\begin{array}{l}\text { 電動機式 } \\
\text { 液 圧 式 }\end{array}$ \\
\hline 制 御 監 & 谷視 盤 & $\begin{array}{l}\text { 監 視 盤 } \\
\text { サイリスタ制御盤 } \\
\text { DC制御盤 } \\
\text { 低圧動力盤 } \\
\text { 電極制御盤 } \\
\text { 計器制御盤 }\end{array}$ & $\begin{array}{l}\text { 監 視 盤 } \\
\text { 低圧動力盤 } \\
\text { 電極制御盤 } \\
\text { 計器制御盤 }\end{array}$ \\
\hline そ & 他 & 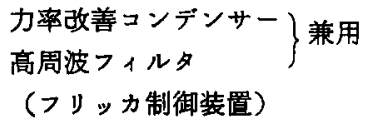 & $\begin{array}{l}\text { 力率改善コンデンサー } \\
\text { 高周波フィルタ } \\
フ \text { フッッカ制御装置 }\end{array}$ \\
\hline
\end{tabular}


表 2 アーク炉の電磁障害とその対策

\begin{tabular}{|c|c|c|c|}
\hline ノイズ分類 & 障害内容 & 障害原因 & アーク炉に拈ける対策設備 \\
\hline \multirow{2}{*}{ 伝 播 性 } & 低力率 & $\begin{array}{l}\text { 力率が悪く } \\
\text { 特性が非線形 }\end{array}$ & 力率改善設備 \\
\hline & 高 調 波 & 電王・電流が歪波形 & 高調波フィルタ \\
\hline 電磁障害 & フリッカ & $\begin{array}{l}\text { 電流、電力が } \\
\text { 時々刻々不規則に } \\
\text { 急激な変化をする }\end{array}$ & フリッカ補供装置 \\
\hline $\begin{array}{l}\text { 近傍放射性 } \\
\text { 電磁 障 害 }\end{array}$ & 界 & $\begin{array}{r}\text { 大電流による } \\
\text { 磁界発生 }\end{array}$ & $\begin{array}{l}\text { 絶縁対策（交流磁界） } \\
\text { 磁化防止（直流磁界） } \\
\text { シールド }\end{array}$ \\
\hline
\end{tabular}

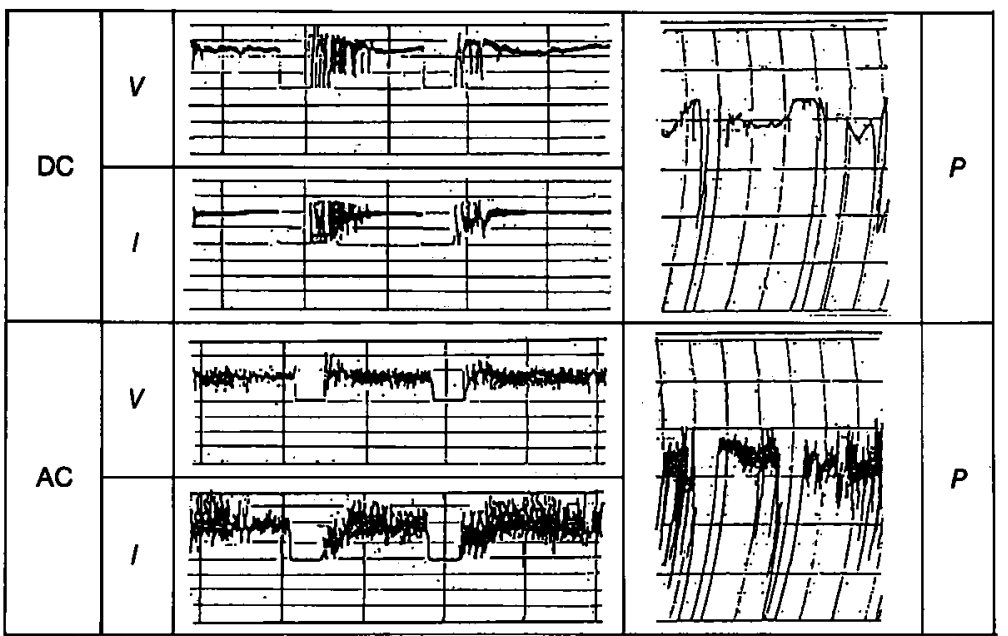

図 1 アーク炉の電圧, 電流, 電力の央湖例

下のようになる。

（1）負荷率が悪い

（2）力率が悪く，力率・電流特性が非線形であ る。

（3）電流が歪波形である。

(4) 電流, 電力が時々刻々不規則に急激な变化 をする。

(5) AC 炉においては，三相各相が不平衡にな る。

\section{1 .1 フリッカ発生量}

負荷変動による電源電王の変動は，照明，テレ ビ, コンビュータ，機峨装直などに対して，それ
ぞれ異なった悪影響を与えるはずである。しかし それらに対する量的な解析も複雑であるため，ま ずは照明,テレビの明るさのちらつきを対象にし， これをフリッカ(Flicker) と呼んでいる。

人間の目が一番ららつきを強く感つる電圧動摇 の周波数は $8 \sim 10 \mathrm{~Hz}$ であり，そのため $10 \mathrm{~Hz}$ 正弦 波動摇に対する規制が実施されている。

図 2 にC 炉と $\mathrm{DC}$ 炉のフリッカの測定例を示 $す^{2)}$

これは, DC 炉のフリッカが $\mathrm{AC}$ 炉の約 $50 \%$ と なることを示しており，DC炉の利点といえる。 この測定結果は, 理論的に以下のよらに説明で 

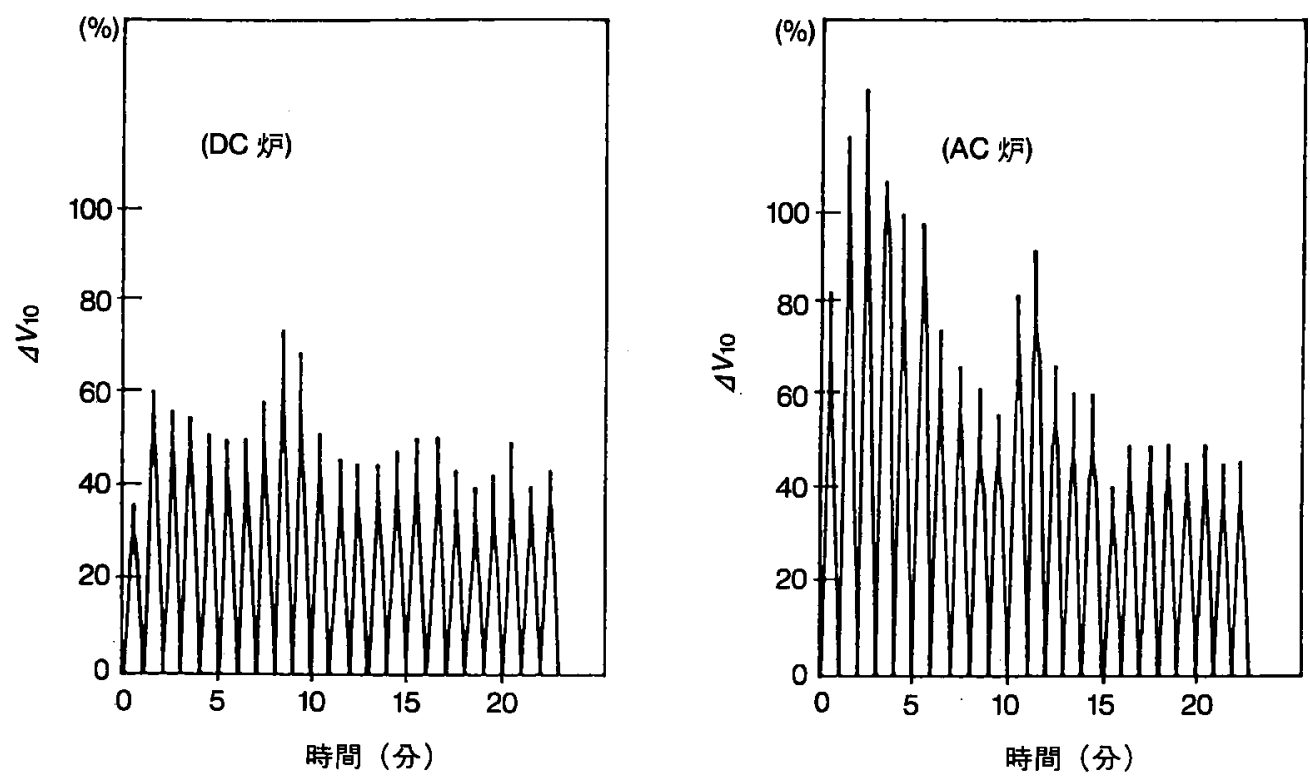

図 2 フリッカー比較

きる。

系統インピーダンス $Z_{\mathrm{s}}=R_{\mathrm{s}}+j X_{\mathrm{s}}$ の電源にア ーク炉負荷を接続した場合, アーク炉一次側の母 線電圧動摇は，下式で表わされる。

$\Delta V \fallingdotseq R_{\mathrm{s}} \cdot \Delta P+X_{\mathrm{s}} \cdot \Delta Q$

ここで $\Delta \mathrm{P}:$ 有効電力の変動 $\Delta Q:$ 無効電力の変動

$R_{\mathrm{s}}$ : 電源の抵抗

$X_{\mathrm{s}}$ : 電源のリアクタンス

一般に，電源の系統インピーダンスは， $R_{\mathrm{S}} \ll$ $X_{\mathrm{s}}$ である。したがって $\Delta V$ は $X_{\mathrm{s}}$ と $\Delta Q$ が支配的 となるため，一般に(1)式の代りに(2)式を用いてフ リッカが検討される。

$\Delta V \fallingdotseq X_{\mathrm{s}} \cdot \Delta Q$

同じ電力系統に同じ変王器容量の $\mathrm{AC}$ 炉と $\mathrm{DC}$ 炉を設置した場合（2)式に捣いて， $X_{5}$ が同じであ るから $\Delta Q$ が問題となる。

一方，AC炉および，電流一定制御を実施した場 合の DC 炬の有効電力 $(P)$ および無効電力 $(Q)$ の関係は，(3)式，(4)式のようになる ${ }^{3), 4) 。 ~}$

$$
\begin{array}{ll}
\text { (AC 炉) } & \left(P^{2}+(Q-A)^{2}=A^{2}\right. \\
\text { (DC 炉) } & P^{2}+Q^{2}=T^{2}
\end{array}
$$

ここで, $A=3 V^{2} / 2 X$

$$
V ： \text { 負荷時二次相電圧 }(\mathrm{V})
$$

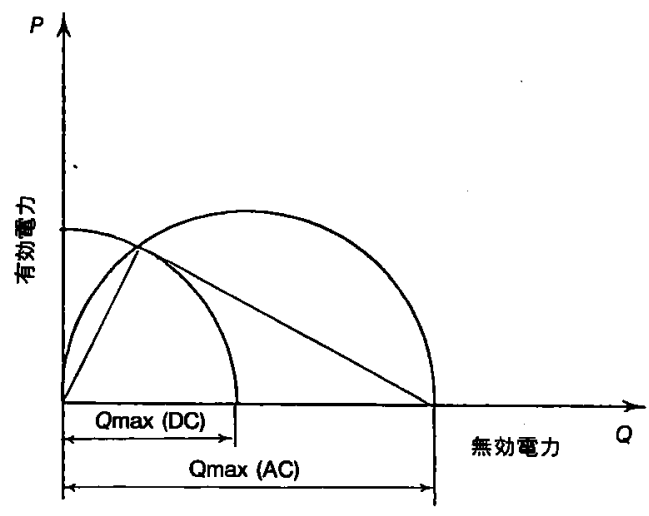

図 3 有効電力一無効電力特性

$X:$ 回路リアクタンス $(\Omega)$

$T$ : 変圧器容量 (kVA)

この(3)式，(4)式をグラフにしたるのを図 3 に示 †.

\section{1 .2 フリッカ補嵄装置}

表 3 にフリッカ補償装置の分類を示す。 上記(2)式において $\Delta V$ を小さくするためには， $X_{\mathrm{s}}$ を低減させる方法と， $\Delta Q$ を補偵する方法があ る。 
表 3 フリッカ補傥装置の分類

\begin{tabular}{|c|c|c|c|}
\hline $\begin{array}{l}\text { 設置 } \\
\text { 場 }\end{array}$ & 補傥の考方方 & 補 傥 の 方 法 & 補償の方式 \\
\hline \multirow{2}{*}{$\begin{array}{l}\text { 電 } \\
\text { 源 } \\
\text { 側 }\end{array}$} & \multirow{2}{*}{$\begin{array}{r}\text { 電源リアクタンス } \\
\text { の補償 }\end{array}$} & $\begin{array}{l}\text { 専用供給 } \\
\text { 電圧の格上げ }\end{array}$ & 系統変更 \\
\hline & & $\begin{array}{l}\text { 直列コンデンサ方式 } \\
\text { 三巻線補偵変圧器方式 }\end{array}$ & \multirow{3}{*}{ 直列補㑽 } \\
\hline \multirow[b]{2}{*}{ 荷 } & $\begin{array}{r}\text { 母線㝦圧降下 } \\
\text { の補㑽 }\end{array}$ & $\begin{array}{l}\text { ブースタ（昇王器）方式 } \\
\text { 相互補償 リアクトル方式 }\end{array}$ & \\
\hline & $\begin{array}{r}\text { アーク電流変動 } \\
\text { の補償 }\end{array}$ & $\begin{array}{l}\text { 直列リアクトル方式 } \\
\text { 直列可飽和リアクトル方式 }\end{array}$ & \\
\hline 側 & $\begin{array}{l}\text { 無効電力変動 } \\
\text { の補供 }\end{array}$ & $\begin{array}{l}\text { 同期調相機と緩衝リアクトル方式 } \\
\text { 並列可飽和リフクトル方式 } \\
\text { サイリスタ型コンデンサ開閉方式 } \\
\text { サイリスタ型リフクトル制御方式 }\end{array}$ & 並列補償 \\
\hline
\end{tabular}

表 4 アーク炉高調波発生予測量

\begin{tabular}{|c|c|c|c|c|c|c|c|c|c|c|c|c|}
\hline アーク炉分類 & $\begin{array}{l}\text { 䚄淁值 } \\
\text { 間 }\end{array}$ & 基本波 & 2 & 3 & 4 & 5 & 6 & 7 & 11 & 13 & 17 & 19 \\
\hline \multirow{4}{*}{ AC炉 } & 2 秒 & $100 \%$ & 20.4 & 18.9 & 8.2 & 8.2 & 3.9 & 3.1 & & & & \\
\hline & 20秒 & $100 \%$ & 9.9 & 13.1 & 4.9 & 5.8 & 2.6 & 2.2 & & & & \\
\hline & 2 分 & $100 \%$ & 7.4 & 9.1 & 3.5 & 5.0 & 1.9 & 1.9 & & & & \\
\hline & 10分 & $100 \%$ & 5.7 & 7.2 & 2.5 & 4.3 & 1.5 & 1.7 & & & & \\
\hline $\begin{array}{l}\mathrm{DC} \text { 炉 } \\
\text { (6相整流) }\end{array}$ & & $100 \%$ & 1.0 & 1.0 & 1.0 & 20.0 & 1.0 & 14.3 & 9.1 & 7.7 & 5.8 & 5.3 \\
\hline
\end{tabular}

専用線化，電压格上げなど $X_{\mathrm{s}}$ そのものを低減さ せるもの，負性リフクタンスを接続し，次式

$$
\Delta V=\left(X_{\mathrm{s}}-X_{\mathrm{c}}\right) \Delta Q
$$

のように $X_{\mathrm{s}}$ を低減させる方法があるが,これら の方法は母線より電源側で設置しなければならな いので, 変動の発生源で処理できない欠点がある。 しかし， $\Delta Q$ を補償する並列補偵型のコンデンサ 開閉式などは，フリッカを発生源で処理できる長 所があり，現在一番多く使用されている。

補償された母線電圧変動は，(6)式となる。

$$
\Delta V=X_{\mathrm{s}} \cdot\left(\Delta Q-\Delta Q_{\mathrm{c}}\right)
$$

ここで, $\Delta Q_{\mathrm{c}}$ ：補償装置が吸収する無効電力変 動

\subsection{3 高調波発生量}

安定状態の AC 师に打いても，アーク電圧， ア 一ク電流は，正弦波波形に比べて乱れた波形にな っているため，相当の高調波分を含んでいること
になる。また，それに加えてスクラップ溶解によ る急激な放奄距離の变化, 雾囲気ガスの流れ, 溶 鋼の摇動などの影響を受けてさらに複雑になって いる。

一方 DC 妒においても，サイリスタ整流装置に 扣いて，サイリスタ点弧角を制御し直流電流一定 制御を行っているため，供給側の三相交流は高調 波を含んでいる。

$\mathrm{AC}$ 炉および DC 炉の高調波予測発生量を表 4 に示す。

$\mathrm{AC}$ 炉の高調波予測発生量が，日本電熱協会】 ーク炉委員会レポート（1988年）で数多くのデー タにより決定された。DC炉の高調波予湘発生量 は, 6 相整流の整流装置の理論值である。

表 5 に DC 炉の高調波測定例を示す。測定に使 用した炬には，定格直流出力 $9.8 \mathrm{MW}$, 定格直流電 流40kAの 6 相整流装置が設置されている。 
表 5 DC妒高調波湘定データ

\begin{tabular}{r|r|r|r|r|r|r|r|r|r|r|r|r}
\hline 測定時期 & カウンタ值 & 基本波 & 2 & 3 & 4 & 5 & 6 & 7 & 11 & 13 & 17 & 19 \\
\hline & 理論值 & $100 \%$ & 1.0 & 1.0 & 1.0 & 20.0 & 1.0 & 14.3 & 9.1 & 7.7 & 5.8 & 5.3 \\
\hline 溶解初期 & 30 & $100 \%$ & & & & 17.8 & & 7.9 & 5.3 & 6.3 & 1.3 & 1.5 \\
\hline 溶解変動期 & 42 & $100 \%$ & & & & 15.8 & & 9.4 & 4.0 & 2.7 & 1.3 & 1.2 \\
\hline 溶 解 期 & 60 & $100 \%$ & & & & 15.8 & & 7.5 & 3.8 & 3.2 & & \\
\hline 精 鍊 期 & 625 & $100 \%$ & & & & 17.8 & & 10.0 & 5.0 & 2.1 & 1.0 & 1.7 \\
\hline 精 錬 期 & 650 & $100 \%$ & & & & 17.8 & & 11.2 & 4.5 & 4.0 & 1.6 & 1.0 \\
\hline
\end{tabular}

DC妒： 6 相整流，定格直流出力 $9.8 \mathrm{MW}$ ，定格電流 $40 \mathrm{kA}$

$A C$ 炉は DC 炉に比ぺて，第 2 〜第 5 の低次領 域で大きな值を示すが， 7 次以上の高次について は小さくなる。

\subsection{4 高 調 波対策}

高調波発生量に関しては，各次調波括よび総合 に対し，電圧歪率の規制が設定されており，下記 に示すような高調波対策が実施されている。

（1）高調波フィルタの取り付け

対象高調波に対して低インピーダンスとなる LC 回路を設置し，高調波を分流し，電源側流出量 を削減させる方法

（2）サイリスタ整流装置の高バルス化

サイリスタ整流装置を12相，24相などの高バル ス整流を導入することにより，整流装置が発生す る高調波発生量を削減する方法

（3）運転時の制御遅れ角低減

整流器用变圧器に負荷時タッブ切换器を設備 し，運転時の設定電圧に応じたタッブ電圧を選定 することにより，サイリスタの点弧角を正弦波に 近い角度で制御させて高調波を低減する方法

(4) 受電電圧の格上げ

受電電圧を高電圧化することにより基本波電流 を低減し，電圧雨率を低減する方法

\section{2 近塝放射性奄磁障害}

\subsection{1 アーク炉の発生する磁界}

$\mathrm{AC}$ 师では500〜600V， 50 60kA の三相交流を 用い, $\mathrm{DC}$ 炉では300 600V， 30～120kA の直流を 取り扱らため，いずれも大電流がすたらす強磁界 による電磁障害が発生する。

图 4 KAC炉5)，图 5 にDC炬における磁界の 測定結果を示す。

$\mathrm{AC}$ 炉の場合の交流電流は，時々刻々大きく変
化するため，正確に計算することは困難である。 しかし DC 炬に执いては，直流電流一定制御を行 っているため磁界計算は AC 炉に比べて計算誤差 が少ないむのになる。

上部電極および炉底電極に電流を導く二次導体 の配置を考虑し，Biot-Savart の法則を用いて酸 界の強度を求あることができる。測定例が数少な いので十分な確認はとれていないが，注は磁界測 定結果と一致すると思われる。

また， AC 炉，DC炉共にアーク柱自体が，二次 尊体回路㧍よび電極が発生する磁界によりフンペ ールの力を受けて斜行していることがよく知られ ている。

\subsection{2 アーク炉発生磁界対策}

上記で述べたアーク炉が発生する電磁障害に対 しては，フーク炉全体を遮へいすることは構造的 に不可能であり，個別に対策を実施することにな る。

周辺の構造物に対しては絶緑対策が実施されて いる。AC炬においては電磁誘導に上る加熱を防 ぐため無筋範囲の設定や，閉ループを作る構造の 回避が行われている。

また，DC炬に怙いては，直流磁界による磁化を 防止するため，一部の部品はステンレス鋼を使用 するなどの注意が厸われている。

\subsection{3 エレクトロニクス製品の磁界対策}

アーク炉が発生する磁界から，操作室内など周 辺に設置したエレクトロニクス製品を保護するに は，磁気シールドを実施しなければならない。

設置場所および設置する方向により磁気の影響

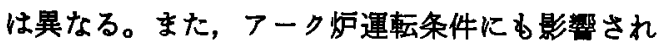
るので，一般には設置場所での最大磁界強さを基 
〈測定位置〉

(1) 平面図

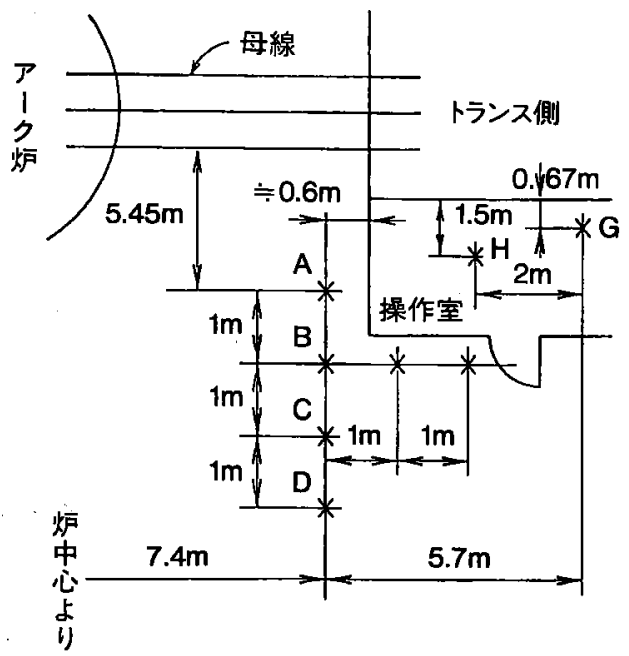

(2) 正面図

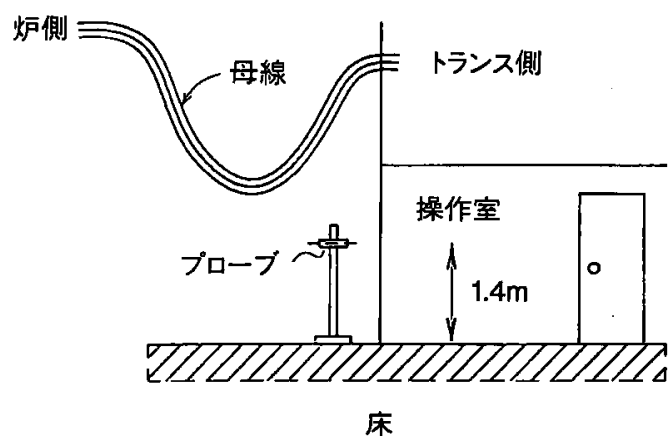

Z方向

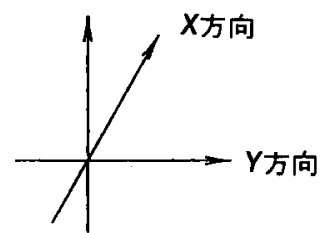

〈測定結果（床上 1400mmの位置を測定）〉

\begin{tabular}{|c|c|c|c|c|c|c|c|c|c|c|c|c|}
\hline \multirow{2}{*}{\multicolumn{2}{|c|}{ 工程 }} & \multicolumn{4}{|c|}{1} & \multirow{2}{*}{\multicolumn{2}{|c|}{ 工程 }} & \multicolumn{4}{|c|}{2} & \multirow{2}{*}{ 備考 } \\
\hline & & $x$ & $Y$ & $z$ & 1 & & & $x$ & $y$ & $Z$ & 1 & \\
\hline \multirow{2}{*}{$\begin{array}{l}\text { 溶 } \\
\text { 解 }\end{array}$} & A & $4^{G}$ & $2^{G}$ & $2.5^{\mathrm{G}}$ & $\begin{array}{c}\mathrm{kA} \\
(50)\end{array}$ & \multirow{5}{*}{$\begin{array}{l}\text { 溶 } \\
\text { 解 }\end{array}$} & A & $4.5^{G}$ & $2.3^{\mathrm{G}}$ & $2^{G}$ & $\begin{array}{c}\mathrm{kA} \\
(50)\end{array}$ & \multirow{5}{*}{ 操作室内 } \\
\hline & $B$ & 4 & 2.3 & 1.5 & (40) & & B & 3 & 2 & 1 & $(50)$ & \\
\hline \multirow{2}{*}{$\begin{array}{l}\text { 精 } \\
\text { 錬 }\end{array}$} & $A$ & 2.2 & 1.4 & 0.9 & (40) & & C & 2.5 & 1.8 & 1 & (50) & \\
\hline & $c$ & 3 & 2.2 & 2 & $(40)$ & & $\mathbf{G}$ & 0.8 & 1 & 0.2 & $(50)$ & \\
\hline \multirow{5}{*}{$\begin{array}{l}\text { 成 } \\
\text { 分 } \\
\text { 調 } \\
\text { 整 }\end{array}$} & B & 3.5 & 2.2 & 2 & (40) & & H & 0.4 & 1.5 & 1.8 & (50) & \\
\hline & C & 2.5 & 1.5 & 1.1 & (40) & \multirow{4}{*}{$\begin{array}{l}\text { 追 } \\
\text { 溶 } \\
\text { 解 }\end{array}$} & C & 3 & 1.6 & 1.8 & $(60)$ & \\
\hline & & & & & & & D & 2.5 & 1.3 & 1 & $(60)$ & \\
\hline & $\ldots$ & & & & & & $E$ & 3 & 2.5 & 1.5 & (60) & \\
\hline & & & & & & & $F$ & 2 & 2.3 & 1.3 & $(60)$ & \\
\hline
\end{tabular}

図 4 AC 炉磁界測定結果 


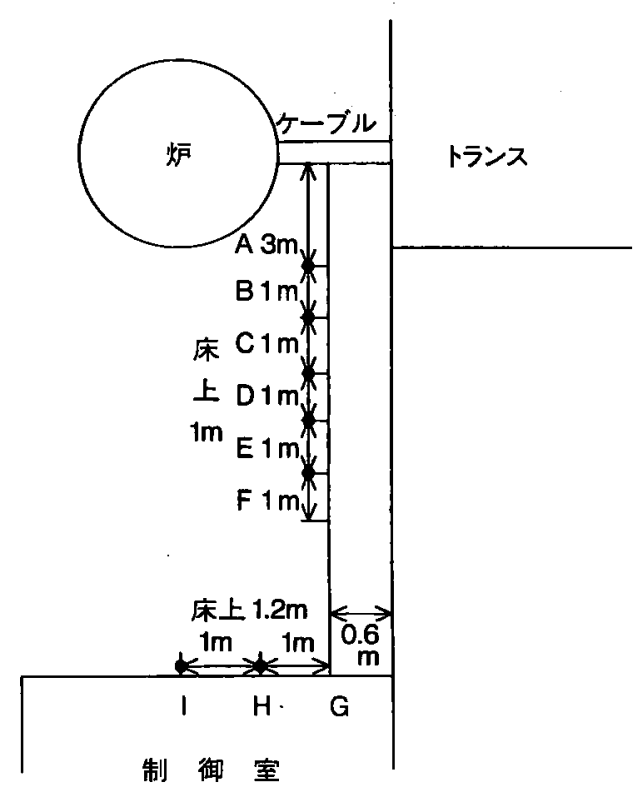

\begin{tabular}{|c|c|c|c|c|}
\hline 測定点 & $x(G)$ & $Y(G)$ & $Z(G)$ & $I(\mathrm{kA})$ \\
\hline B & 5.6 & 0.5 & 0.3 & \multirow{5}{*}{19.2} \\
\hline C & 4.8 & $\overline{0.5}$ & 0.5 & \\
\hline D & 3.3 & 0.5 & 0.6 & \\
\hline$E$ & 2.5 & 0.7 & 0.3 & \\
\hline$F$ & 2.0 & 0.6 & 0.2 & \\
\hline A & 21.1 & 4.8 & 0.5 & \multirow{9}{*}{24.1} \\
\hline B & 10.3 & 0.9 & 1.4 & \\
\hline C & 7.0 & 0.6 & 0.7 & \\
\hline $\bar{D}$ & 4.2 & 0.7 & 0.7 & \\
\hline $\bar{E}$ & 3.4 & 0.7 & 0.5 & \\
\hline$F$ & 2.7 & 0.7 & 0.4 & \\
\hline $\mathbf{G}$ & 3.4 & 0.6 & 0.15 & \\
\hline $\bar{H}$ & 1.9 & 0.55 & 0.6 & \\
\hline 1 & 1.1 & 0.6 & 0.4 & \\
\hline
\end{tabular}

図 5 DC 炉磁界測定結果

準值として磁気シールド対策が実施される。

磁気シールド材料としては，現在いろいろな材 料が開発され使用されているが，フーク炉工場の よらな強磁界環境では高透磁率材料が用いられ る。たとえば, VDT の磁気シールドとしてPCパ ーマロイが数多く使用され実績を上げている。実 際の設計にあたっては，板厚および透磁率を確認 し考慮する必要がある。

4. むす $ォ$

アーク炉工場に抹ける電磁障害は伝播性障害に 関しては, 古くから研究されており，その成果も 数多く，現在ではほとんどが対策されている。し かし放射性障害に成する研究は，前者ほど進んで おらず未解決の問題す多く存在している。

21世紀に向けて「クリーンに廃棄物をリサイク ルする」ためには，製鋼用アーク炉，特に DC 炬は 必要不可欠な設備であり， $\mathrm{CO}_{2}$ 排出規制の面から
も他のシステムより優れている。今後ますますフ 一ク炉設備は電気エネルギー密度を増大させる必 要が生じる中で, EMC (電磁協調) は重要度を増 しており，作業環境も含めた改善努力を関係者各 位と共に続けたいと考えている。

最後に，御協力いたたいた侏東芝执よび当社星 崎工場ならびに商品開発部の皆様に感謝すると共 に、お礼申し上げる。

(文

献)

1) 稲垣悦郎：アーク炉の電熱, (1984)大同特殊 鋼編

2) T.Noda : 6th IISC Paper, 4 (1990), 200

3）工業電気加熱ハンドブック〔日本電熱工学委 員会]

4）エレクトロヒート応用ハンドブック〔日本電 熱協会]

5）和泉喜久磨：計湘技術，16（1988）11，209 